\title{
D1-like and D2-like Dopamine Receptors Synergistically Activate Rotation and c-fos Expression in the Dopamine-depleted Striatum in a Rat Model of Parkinson's Disease
}

\author{
M. L. Paul, ${ }^{1}$ A. M. Graybiel, ${ }^{2}$ J.-C. David, ${ }^{3}$ and H. A. Robertson ${ }^{1}$ \\ 'Department of Pharmacology, Dalhousie University, Halifax, Nova Scotia, Canada B3H 4H7, ${ }^{2}$ Department of Brain and \\ Cognitive Science, Massachusetts Institute of Technology, Cambridge, Massachusetts 02139 and ${ }^{3}$ Departement de \\ Biochimie, Université de Rennes I, 35092 Rennes, France
}

\begin{abstract}
Selective agonists for $\mathrm{D} 1$-like and D2-like dopamine receptors can interact synergistically to enhance each other's actions on locomotion and behavior in experimental animals. Clinically, the combination of the D2 agonist bromocriptine with L-dopa (which has pronounced D1 effects) is a highly effective treatment for Parkinson's disease. The mechanisms underlying this important receptor interaction are poorly understood and are the subject of intense study in vitro. In rats with unilateral 6-hydroxydopamine (6-OHDA) lesions of the nigrostriatal pathway, D1-selective (but not D2-selective) dopamine agonists produce a marked increase in expression of the immediate-early gene c-fos in the striatum ipsilateral to the 6-OHDA lesion. In the experiments reported here, we have used this in vivo model to explore the possibility that combinations of D1-selective and D2-selective agonists might have effects on c-fos transcription that are different from those exhibited by D1 or D2 agonists administered alone.
\end{abstract}

We examined the effects of the D1-selective agonist SKF38393 and the D2-selective agonist quinpirole (LY 171555) on the expression of Fos-like protein and c-fos mRNA in the caudoputamen and made parallel behavioral observations in the same animals. A low dose of SKF-38393 produced little contraversive rotation and little induction of Fos-like immunoreactivity in the striatum. A low dose of quinpirole elicited contralateral rotation but little or no induction of Foslike immunoreactivity in the caudoputamen; there was, however, induction of Fos in the globus pallidus ipsilateral to the 6-OHDA lesion. Combination of the low dose of SKF-38393 and quinpirole produced a synergistic effect on rotation and elicited, in the dopamine-depleted caudoputamen, a striking pattern of Fos-like protein expression in which Fos-positive neurons were concentrated in striosomes and in the dor-

\footnotetext{
Received Nov. 26, 1991; revised Mar. 12, 1992; accepted Apr. 9, 1992.

We thank K. M. Murphy, M. R. Peterson, and G. Holm for excellent technical support, H. F. Hall for his help with the photography, Dr. R. W. Currie for the $\beta$-actin probe, and Dr. K. G. Baimbridge for the calbindin $D_{28 \mathrm{~K}}$ antiserum. The following drugs were generous gifts: quinpirole (Eli Lilly Laboratories), raclopride (Astra Pharmaceuticals), SCH-23390 (Schering Plough Corporation). This work was supported by the Medical Research Council of Canada Grant MT 10644, The Parkinson Foundation of Canada, and the Human Frontier Science Program M.L.P. is the recipient of a Dalhousie Medical Research Foundation postdoctoral fellowship. J.-C.D. was a Medical Research Council of Canada Visiting Scientist.

Correspondence should be addressed to $\mathrm{H}$. A. Robertson, Department of Pharmacology, Sir Charles Tupper Medical Building, Dalhousie University, Halifax, Nova Scotia, Canada B3H 4H7.

Copyright (C) 1992 Society for Neuroscience $0270-6474 / 92 / 123729-14 \$ 05.00 / 0$
}

solateral caudoputamen. Northern blot analysis showed that c-fos mRNA was expressed following combined agonist treatment but was not detectable after the single-agonist treatments. Both the contraversive rotation and the induction of Fos-like immunoreactivity were blocked by the preadministration of the D1-preferring antagonist SCH-23390 and the D2-selective antagonist raclopride in combination. Pretreatment with the glutamate NMDA receptor antagonist MK-801 also blocked the induction of Fos-like immunoreactivity, and it reversed the rotation. These findings suggest a D1/D2 synergistic mechanism that involves the participation of D1responsive striatonigral and D2-responsive striatopallidal output pathways, and that is sensitive to glutamatergic modulation.

Dopamine exerts a powerful effect on the central regulation of motor activity and behavior by the basal ganglia. The importance of this neurochemical in the CNS is emphasized by the fact that abnormalities in dopamine transmission have been implicated in a wide range of disorders including Parkinson's disease, schizophrenia, and drug addiction (Hornykiewicz, 1979; Koob and Bloom, 1988). Dopamine can mediate its effects within the CNS by interacting with a family of receptor subtypes. The classical D1 and D2 subtypes were identified on the basis of different biochemical, electrophysiological, and pharmacological properties (Kebabian and Calne, 1979; Creese and Fraser, 1987). The recently cloned D3 (Sokoloff et al., 1990), D4 (Van Tol et al., 1991), and D5 (Sunahara et al., 1991) subtypes are not as well characterized, but D1-like (D1, D5) and D2-like (D2, D4) categories are consistent with their known pharmacology. Evidence suggests that D1-like and D2-like receptors have contrasting effects on second messenger systems. For example, activation of pharmacologically defined D1 receptors increases adenylyl cyclase activity and cAMP production, whereas pharmacologically defined D2 receptors inhibit or have no direct effect on this enzyme cascade (Kebabian and Calne, 1979; Stoof and Kebabian, 1981). Within the striatum, these receptor subtypes have further been distinguished as having opposing influences on inositol phosphate formation (Mahan et al., 1990) as well as on neuropeptide expression (Mocchetti et al., 1985; Gerfen et al., 1990; Graybiel, 1990; Jiang et al., 1990).

It is now clear that D1-like and D2-like receptors not only mediate opposing biochemical changes but also can interact to produce synergistic effects on behavior and movement-related functions. Interactions at the behavioral level have been dem- 
onstrated in a number of model systems (Gershanik et al., 1983; Jackson and Hashizume, 1986; Mashurano and Waddington, 1986), including the Ungerstedt rat model of Parkinson's disease (Robertson and Robertson, 1986; Sonsalla et al., 1988). There is some evidence to suggest that such receptor interactions may be relevant to the treatment of Parkinson's disease. Dopamine replacement therapy with $L$-dopa continues to be the most widely used and most effective treatment for Parkinson's disease. However, the combination of the D2 agonist bromocriptine with L-dopa, which has pronounced D1 effects, is often more effective than L-dopa alone (Calne et al., 1974; Rinne, 1987; see also Walters et al., 1987; Weick et al., 1990).

The interactions between D1-like and D2-like receptor mechanisms could occur at a number of different levels. On the one hand, they could be based on differential dopamine receptor locations within the neuronal circuitry interconnecting the striatum, substantia nigra, and pallidum (Robertson and Robertson, 1987; Walters et al., 1987; Graybiel, 1990, 1991; LaHoste and Marshall, 1990; Parent, 1990; H. A. Robertson, 1992). For example, Herrera-Marschitz and Ungerstedt (1984a,b) have proposed the idea that D1 - and D2-mediated rotational behavior may involve activation of separate striatal efferent pathways. Alternatively, they could reflect D1/D2 synergism at the cellular level. Studies conducted on dissociated striatal neurons (Bertorello et al., 1990) and transfected Chinese hamster ovary (CHO) cells (Piomelli et al., 1991) have demonstrated D1/D2 synergistic interactions at the level of the single cell are present in vitro. The occurrence of these biochemical responses in vivo and their significance with respect to D1/D2 synergistic behaviors are yet to be established.

In the work reported here, we have explored the possibility that combinations of D1-selective and D2-selective agonists administered in vivo activate different sets of striatal neurons than those activated by D1 or D2 receptor agonists alone. As a marker of cellular activation, we used the inducton of Fos-like protein detected histochemically (Sagar et al., 1988; Morgan and Curran, 1991), and as a marker of the c-fos gene we monitored c-fos mRNA by Northern blot analysis.

It is already known that D1-selective, but not D2-selective, dopamine agonists can produce dramatic increases in the expression of Fos-like protein in neurons in the denervated striatum of rats given unilateral 6-hydroxydopamine (6-OHDA) lesions of the nigrostriatal pathway (G. S. Robertson et al., 1989; H. A. Robertson et al., 1989). The neurons that generate the Fos response have been identified as medium-sized neurons that project to the substantia nigra pars reticulata (G. S. Robertson et al., 1990a)-neurons that express D1-like receptors (Gerfen et al., 1990). By contrast, the Fos response has not been detected in large numbers of medium-sized neurons that project to the pallidum (G. S. Robertson et al., 1990b). This evidence suggests that in the dopamine-depleted striatum, the induction of Fos or related proteins that is mediated by D1-like receptor activation may predominate in a subset of striatal output pathways. In the experiments reported here, we tested for behavioral D1/ D2 synergy in unilaterally 6-OHDA-treated rats, and in the same animals monitored the Fos response in the striatum and globus pallidus by immunohistochemistry. We used single and combined administration of the D1 agonist SKF-38393 and the D2 agonist quinpirole (LY-171555) to rats with unilateral 6-OHDA lesions. We reasoned that if the behavioral synergy were accompanied by synergistic activation of neurons in the corpus striatum, these monitors of transcriptional activation might show the effects directly. In light of evidence suggesting that glutamatergic pathways can modulate dopamine neurotransmission (Giorguieff et al., 1977; Bolam, 1984; Clow and Jhamandas, 1989), we also examined the effects of the noncompetitive NMDA receptor antagonist MK-801 (Wong et al., 1986) on the D1/D2 synergistic response. Our findings suggest a striking parallel in the behavioral and neuronal synergistic responses and suggest that the syncrgistic bchavioral responsc may depend at least in part on recruitment of separate striatal efferent pathways.

\section{Materials and Methods}

Animal preparation and analysis of rotational behavior. Male SpragueDawley rats weighing 325-350 gm were anesthetized by intraperitoneal (i.p.) injection of sodium pentobarbital $(50 \mathrm{mg} / \mathrm{kg})$, and unilateral lesions of the right medial forebrain bundle were made by injection of $12 \mu \mathrm{g}$ of 6-OHDA HBr (Sigma, St. Louis, MO) (to give $8 \mu \mathrm{g}$ of 6-OHDA free base) in $4 \mu 1$ of sterile saline containing $0.2 \%$ ascorbic acid. Stereotaxic coordinates were $3.7 \mathrm{~mm}$ posterior to bregma, $1.6 \mathrm{~mm}$ right of midline, $8.8 \mathrm{~mm}$ ventral to the skull at the midline, in the flat-skull position (Paxinos and Watson, 1985). The solution was delivered by a microinjection pump, CMA 100 (Carnegie-Medicin), at $0.5 \mu \mathrm{l} / \mathrm{min}$, and the cannula was left in situ for $2 \mathrm{~min}$ after the end of injection. Thirty minutes prior to surgery, rats were given desipramine (Sigma; $25 \mathrm{mg}$ / $\mathrm{kg}$, i.p.) to prevent uptake of 6-OHDA by noradrenergic terminals. Following 3 weeks recovery, the efficacy of the lesion was determined by monitoring contralateral rotation induced by the mixed D1/D2 agonist apomorphine (Research Biochemicals Inc., $0.5 \mathrm{mg} / \mathrm{kg}$, i.p.) in two separate trials. Animals were habituated to the rotation chamber for 15 min prior to drug injection. An automated rotometer recorded the numbers of contraversive turns made in consecutive 10 min periods for 60 min. Only those animals that turned 70 or more turns $/ 10$ min in both trials were included in the study.

Drug treatment. One week after the second apomorphine challenge, animals were randomly assigned to one of nine experimental groups (five animals per group) and were given three successive drug treatments at $t=0,30 \mathrm{~min}$, and $70 \mathrm{~min}$, as summarized in Table 1. All drugs were given by intraperitoneal injection at the following doses: the DI-selective agonist SKF-38393 (Research Biochemicals Inc.), $0.5 \mathrm{mg} / \mathrm{kg}$; the D2-selective agonist quinpirole (Eli Lilly Corp.), $0.25 \mathrm{mg} / \mathrm{kg}$; the D1selective antagonist SCH-23390 (Schering Plough Corp.), $0.5 \mathrm{mg} / \mathrm{kg}$; the D2-selective antagonist raclopride (Astra Pharmaceuticals), $2.0 \mathrm{mg} / \mathrm{kg}$; and the noncompetitive NMDA glutamate receptor antagonist MK-801 (Research Biochemicals Inc.) $0.1,0.5$, or $1.0 \mathrm{mg} / \mathrm{kg}$. Mean rotation rates, calculated over the first (0-30 $\mathrm{min})$, second (30-70 $\mathrm{min})$, and third (70-130 min) treatment periods, were compared by an overall test of significance using an $F$ ratio derived from one-way analysis of variance. In cases in which the null hypothesis was rejected, a post hoc NewmanKeuls multiple comparison test was performed.

Immunohistochemistry. Two hours after the last drug injection, rats were deeply anesthetized with sodium pentobarbital ( $>70 \mathrm{mg} / \mathrm{kg}$, i.p.) and were perfused transcardially with $0.1 \mathrm{M}$ phosphate-buffered saline (PBS) followed by $4 \%$ paraformaldehyde in $0.1 \mathrm{~m}$ phosphate buffer $(\mathrm{pH}$ 7.4). Brains were removed, postfixed for $48 \mathrm{hr}$, blocked, and cut coronally on a vibratome at $40 \mu \mathrm{m}$. Serial sections taken through the striatum were stained in sets for Fos-like immunoreactivity by following a modified avidin-biotin immunohistochemical protocol (Hsu et al., 1981 ), with a polyclonal antiserum raised in sheep against a Fos peptide (1:2000; Cambridge Research Biochemicals, Cambridge, UK). In some brains, serial sections were stained for calbindin- $D_{28 \mathrm{~K}}$-like immunoreactivity, a striatal matrix-specific marker (Gerfen et al., 1985), with a polyclonal antiserum raised in rabbit (gift of Dr. K. G. Baimbridge, University of British Columbia; 1:2000). Selected sections through the striatum were stained with antiserum against tyrosine hydroxylase (1: 2000; Eugene Tech., Allendale, NJ).

Northern blot analysis. Rats given unilateral 6-OHDA lesions 3 weeks before, and challenged twice with $0.5 \mathrm{mg} / \mathrm{kg}$ apomorphine, were treated with agonists according to the protocols for the behavioral experiments, and were killed by decapitation $45 \mathrm{~min}$ after administration of either SKF-38393 (group I, $n=4$ ), quinpirole (group II, $n=4$ ), or the combination of the two drugs (group III, $n=4$ ). The brains were removed, and the left (intact) and right (6-OHDA-denervated) striata were rapidly excised, pooled by group and by side, and immediately frozen in liquid 
Table 1. Summary of rotational behavior in rats with unilateral 6-OHDA lesions following single and combined administration of SKF-38393 $(0.5 \mathrm{mg} / \mathrm{kg})$ and quinpirole $(0.25 \mathrm{mg} / \mathrm{kg})$

\begin{tabular}{|c|c|c|c|c|c|c|}
\hline \multirow[b]{2}{*}{ Group } & \multicolumn{2}{|c|}{$1 \mathrm{st}$ treatment $(t=0 \mathrm{~min})$} & \multicolumn{2}{|c|}{2 nd treatment $(t=30 \mathrm{~min})$} & \multicolumn{2}{|c|}{$3 \mathrm{rd}$ treatment $(t=70 \mathrm{~min})$} \\
\hline & Drug & $\begin{array}{l}\text { Rotations/ } \\
10 \mathrm{~min}\end{array}$ & Drug & $\begin{array}{l}\text { Rotations/ } \\
10 \mathrm{~min}\end{array}$ & Drug & $\begin{array}{l}\text { Rotations/ } \\
10 \mathrm{~min}\end{array}$ \\
\hline I & Saline & $0.9 \pm 0.2$ & SKF & $1.2 \pm 0.6$ & Saline & $1.3 \pm 0.5$ \\
\hline II & Saline & $1.1 \pm 0.2$ & Quinpirole & $71.0 \pm 10.2^{a}$ & Saline & $54.4 \pm 13.2^{b}$ \\
\hline III & Saline & $1.0 \pm 0.4$ & SKF & $4.0 \pm 1.2$ & Quinpirole & $115.6 \pm 11.9^{\circ}$ \\
\hline IV & Saline & $0.1 \pm 0.1$ & SKF & $0.7 \pm 0.1$ & SKF & $0.9 \pm 0.2$ \\
\hline $\mathrm{V}$ & Saline & $0.3 \pm 0.1$ & Quinpirole & $87.6 \pm 10.6^{a}$ & Quinpirole & $82.8 \pm 5.1^{c, d}$ \\
\hline VI & SCH -23390 & $1.2 \pm 0.4$ & SKF & $1.7 \pm 0.2$ & Quinpirole & $46.6 \pm 5.7^{d}$ \\
\hline VII & Raclopride & $1.5 \pm 1.4$ & SKF & $2.2 \pm 0.4$ & Quinpirole & $23.0 \pm 13.7^{d}$ \\
\hline VIII & $\mathrm{SCH} / \mathrm{rac}$ & $1.8 \pm 0.8$ & SKF & $5.7 \pm 2.4$ & Quinpirole & $6.7 \pm 5.0^{d}$ \\
\hline
\end{tabular}

SCH-23390 and raclopride were administered in doses of $0.5 \mathrm{mg} / \mathrm{kg}$ and $2.0 \mathrm{mg} / \mathrm{kg}$, respectively. Values represent the mean $( \pm$ SEM) number of contraversive rotations. $n=5$ in each group.

${ }^{\circ} p<0.001$ compared to all groups.

${ }^{n} p<0.05$ compared to groups I or III.

${ }^{c} p<0.05$ compared to groups I or II.

${ }^{d} p<0.05$ compared to group III using ANOVA and Student Newman-Keuls test for significance.

nitrogen. Total RNA was extracted using an InVitrogen isolation kit, which is based on the guanidine isothiocyanate method of Chirgwin et al. (1979). Following purification with oligo-dT cellulose, polyA ${ }^{+}$mRNA $(1 \mu \mathrm{g})$ was separated by electrophoresis through a $1 \%$ agarose-formaldehyde gel, transferred to a nylon membrane (Zeta probe, Bio-Rad), and fixed by UV irradiation. Membranes were probed for c-fos mRNA with an oligonucleotide probe (sequence, 5'-GCA GCG GGA TGA GGC CTC GTA GTC CGC GTT GAA ACC CGA GAA CAT-3') 3' end-labeled with $\alpha{ }^{32} \mathrm{P}$-dATP, and for $\beta$-actin mRNA with a pDmA plasmid (Fryberg et al., 1980) that was digested with HindIII to produce a 1.8 kilobase fragment coding for the Drosophila actin gene. This probe was nick translated using the multiprime DNA labeling system of Du Pont-NEN and $\alpha-{ }^{32}$ P-dCTP.

\section{Results}

D1/D2 synergistic responses. In rats with unilateral 6-OHDA lesions, combined treatment with $\mathrm{D} 1$ and $\mathrm{D} 2$ dopamine receptor agonists produced a synergistic enhancement of rotational behavior (Fig. 1A, Table 1). A low dose of the D1-selective agonist SKF-38393 $(0.5 \mathrm{mg} / \mathrm{kg})$ by itself (group I) had no effect on rotation, whereas the D2-selective agonist quinpirole $(0.25 \mathrm{mg}$ / $\mathrm{kg}$ ), when given alone (group II), induced a rapid increase in contraversive tuning that commenced immediately upon injection. Combined administration of the two drugs (group III) produced a turning rate that was significantly higher than the rate that was seen after quinpirole alone $(p<0.05)$. Immunohistochemical analysis demonstrated that the 6-OHDA lesions brought about denervation of practically all the tyrosine hydroxylase-like immunoreactivity in the striatum (Fig. 2).

The D1/D2 synergistic behavioral effect was paralleled by striking contrasts in the level of Fos-like protein expression induced within the denervated striatum by the different drug treatments (Fig. 3). The D1-selective agonist SKF-38393 (0.5 $\mathrm{mg} / \mathrm{kg}$, group I) did not induce intense expression of Fos-like immunoreactivity in the caudoputamen (Fig. $3 C, C$ ), but Fospositive nuclei were scattered through the denervated caudoputamen, especially dorsomedially. Little Fos-like immunoreactivity was evident in the globus pallidus (Fig. $4 A$ ). Treatment with the D2-selective agonist quinpirole $(0.25 \mathrm{mg} / \mathrm{kg}$, group II) produced very little expression of Fos-like immunoreactivity in the striatum (Fig. $3 D, D$ ), even though these animals displayed considerable turning behavior. In contrast to the D1-treated rats, however, those treated with quinpirole showed induction of Fos-like protein in cells of the globus pallidus ipsilateral to the 6-OHDA lesion (Fig. 4B). Fos-like immunoreactivity was also induced in the cortex, including the sensorimotor cortex, and was especially prominent in layers II, III, V, and VI on the side of the 6-OHDA lesion in both the SKF-38393-treated and the quinpirole-treated rats (not illustrated). In none of the rats was Fos-like protein induced in more than an occasional cell of the striatum contralateral to the 6-OHDA lesion.

In marked contrast to these patterns of Fos induction following D1 and D2 agonist treatment, there was pronounced Foslike immunoreactivity in the denervated caudoputamen of rats that had received the combined D1/D2 agonist treatment (group III). As shown in Figure 3A, cells expressing nuclear Fos-like immunoreactivity were distributed in a highly distinctive pattern. At rostral and middle levels of the striatum, there was intense expression of Fos-like immunoreactivity in the dorsolateral caudoputamen. Elsewhere in the caudoputamen, Fospositive cells concentrated in small patches (Fig. $3 A, A^{\prime}$ ), and were relatively scattered outside the patches, in densities roughly comparable to those seen following SKF-38393 treatment alone (Fig. $3 A^{\prime}, C^{\prime}$ ).

Comparisons with serially adjacent sections demonstrated that the Fos-positive patches corresponded to calbindin- $\mathrm{D}_{28 \mathrm{~K}}$-poor striosomes. In fact, as shown in Figurc $3 A-D$, ncarly cvery Fospositive patch had a calbindin- $\mathrm{D}_{28 \mathrm{~K}}$-poor match, and many or most of the calbindin-poor striosomes were Fos positive. Moreover, although the dorsolateral zone of intense Fos positivity did not have sharp borders, it corresponded quite closely to the dorsolateral region of low calbindin- $\mathrm{D}_{28 \mathrm{~K}}$ immunostaining. The striosomal patterning of Fos expression persisted in more caudal sections through the striatum, but the dorsolateral zone of Fos immunostaining tended to diminish in size and intensity along the rostral-caudal axis. Fos-positive cells also were present in the ipsilateral globus pallidus (Fig. 4C) and cortex including motor cortex in distributions similar to those observed in the quinpirole only group. As in the brains of rats treated with D1 or D2 agonists, there were very few Fos-positive cells in the caudoputamen contralateral to the 6-OHDA lesion (Fig. 3E).

Northern blot analysis of striatal tissue (Fig. 5) supported the 

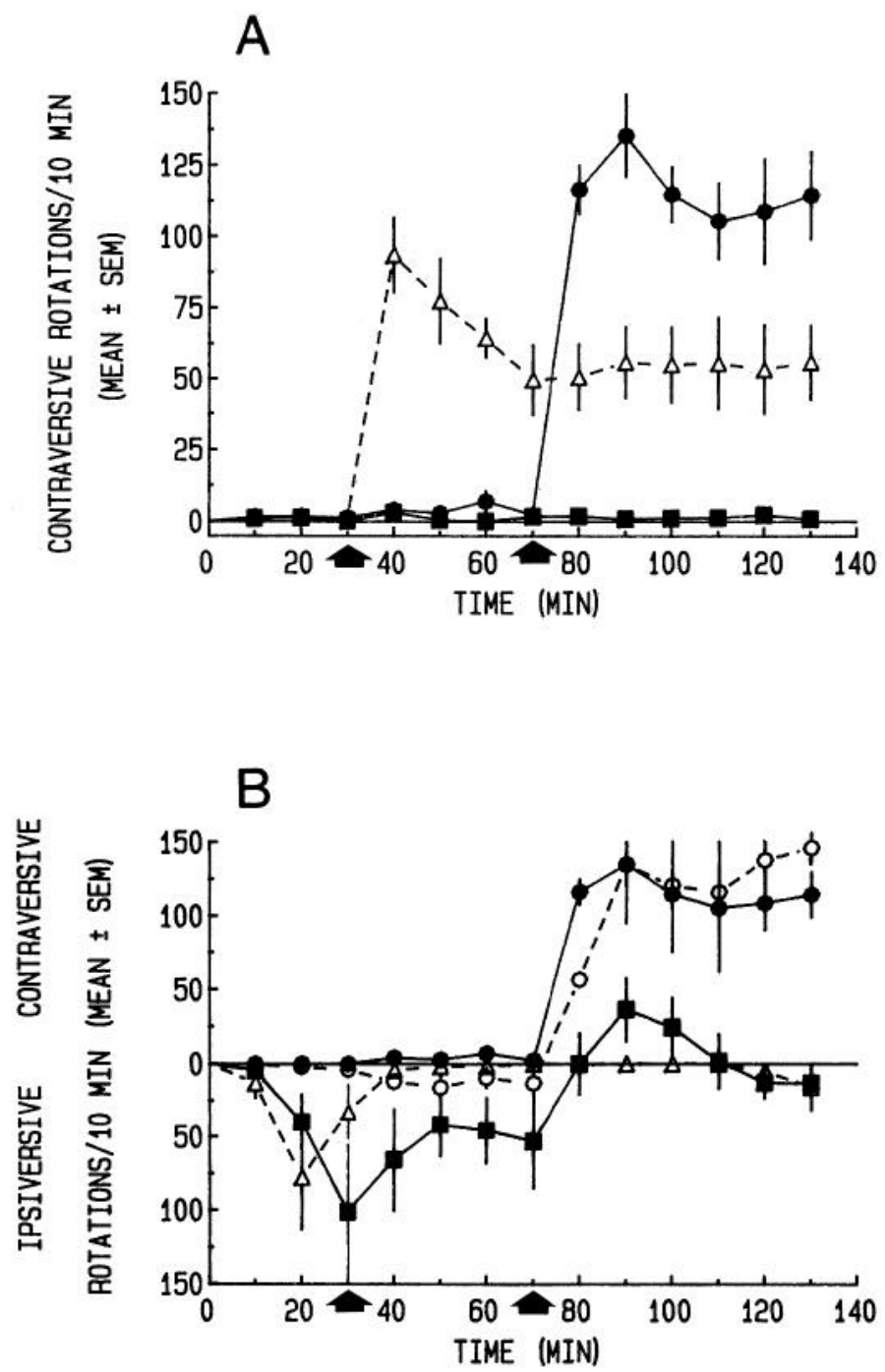

Figure 1. A, The effects of single and combined administration of SKF$38393(0.5 \mathrm{mg} / \mathrm{kg})$ and quinpirole $(0.25 \mathrm{mg} / \mathrm{kg})$ on rotational behavior of rats with unilateral 6-OHDA lesions confirmed by apomorphine challenge. Animals did not turn following injection at $t=30 \mathrm{~min}$ of SKF-38393 (group I, 口), but did exhibit contraversive turning in response to quinpirole (group II; $\Delta$ ). When rats challenged with SKF38393 were given quinpirole $(t=70 \mathrm{~min}$ ) (group III, ๑), significantly more contraversive turning was achieved than with the quinpirole only group. Values represent the mean $\pm \operatorname{SEM}(n=5$ in each group). $B$, The synergistic rotational response elicited by combined SKF-38393 $(t=30$ min) and quinpirole ( $t=70 \mathrm{~min}$ ) administration (group III, $\bullet$ ) was prevented by prior injection $(t=0 \mathrm{~min})$ of the NMDA receptor antagonist MK-801 at $0.5(\square)$ and $1.0(\triangle) \mathrm{mg} / \mathrm{kg}$, but not at the low dose of $0.1 \mathrm{mg} / \mathrm{kg}(\mathrm{O}) . \mathrm{MK}-801$ itself promoted a strong ipsiversive turning response. Values represent the mean $\pm \operatorname{SEM}(n=5$ in each group).

immunohistochemical results. C-fos mRNA was undetectable in the ipsilateral and contralateral striatum of animals given either SKF-38393 (group I) or quinpirole (group II) alone. By contrast, combined administration of SKF-38393 and quinpirole (group III) produced a pronounced increase in the hybridization signal for c-fos mRNA in the striatum ipsilateral to the 6-OHDA lesion. No signal was detected in the contralateral striatum.

Confirmation of the D1/D2 synergistic response. The results just described suggested that the D1/D2 synergistic behavioral response might be correlated with selective activation of specific

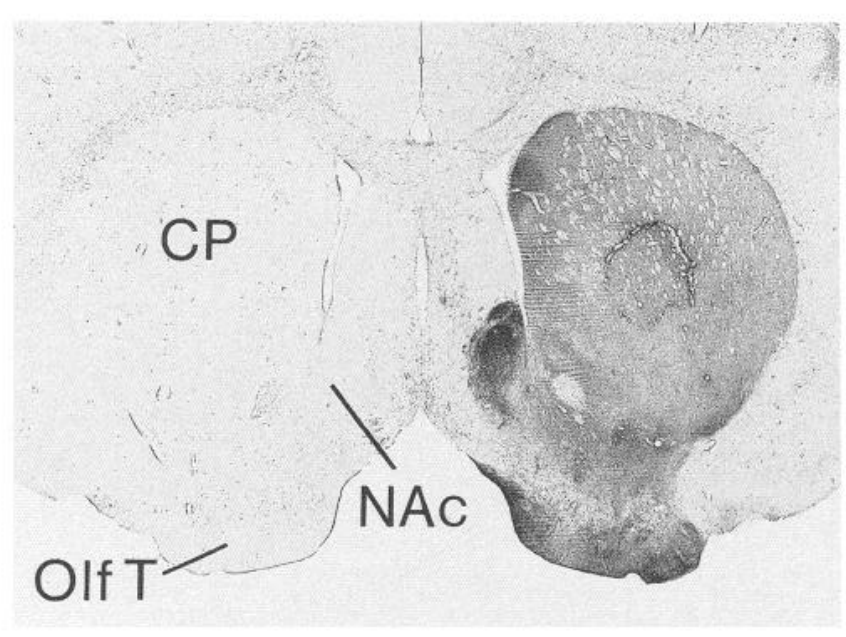

Figure 2. Photomicrograph of a transverse section through the striatum of a rat in the experimental series, stained for tyrosine hydroxylaselike immunoreactivity. The rat was treated with 6-OHDA and challenged with apomorphine as described in Materials and Methods. Tyrosine hydroxylase-like immunoreactivity is depleted on the denervated side. $C P$, Caudoputamen; Olf $T$, olfactory tubercle; $N A_{c}$, nucleus accumbens.

neuronal pathways within the basal ganglia. In order to determine whether the synergistic enhancement of Fos-like protein expression and its specific regional and striosomal distribution were specific to the interaction of D1-like and D2-like receptors activated by the agonist drugs, we examined three other treatment groups. Rats with unilateral 6-OHDA lesions were given two successive injections ( $t=30$ and $t=70 \mathrm{~min}$ ) of either 0.5 $\mathrm{mg} / \mathrm{kg} \mathrm{SKF}-38393$ (group IV) or $0.25 \mathrm{mg} / \mathrm{kg}$ quinpirole (group V).

The responses of rats given two doses of SKF-38393 (group IV) were indistinguishable from the animals that received only one injection of SKF-38393 (group I) in that they exhibited no contraversive rotational behavior (Table 1) and very little expression of Fos-like immunoreactivity in the denervated striatum (Fig. 6A). Animals given two successive injections of quinpirole (group V) achieved a higher turning rate than those that received a single injection (group II), although this rate of rotation was still significantly lower $(p<0.05)$ than the rate elicited by combined SKF-38393 and quinpirole administration (group III) (Table 1). However, animals that received two successive injections of quinpirole did display more Fos-like immunoreactivity in the denervated striatum than was seen following single injection of quinpirole. Fos-positive nuclei were scattered throughout the caudoputamen (Fig. $6 B$ ) and globus pallidus. There were occasional instances of clusters of Fos-positive cells (Fig. $6 B$ ), but the Fos-like immunoreactivity did not have the pronounced dorsolateral quadrant- and striosome-selective pattern of distribution that was seen following combined D1/D2 treatment.

We next asked whether high doses of the D1-selective agonist SKF-38393 would evoke the same patterns of striatal Fos-like protein expression that were seen following combined D1/D2 treatment. The marked preponderance of Fos-like protein in cells of the dorsolateral quadrant and striosomal system had not been noted in previous experiments $(\mathrm{H}$. A. Robertson et al., 1989). A single injection of SKF-38393 at $1.0 \mathrm{mg} / \mathrm{kg}$ elicited low rates of rotation $(4.5 \pm 3.2$ turns $/ 10 \mathrm{~min} ; n=6)$ and little or no induction of Fos-like immunoreactivity in the caudopu- 
tamen (not shown). Given at a dose of $2.0 \mathrm{mg} / \mathrm{kg}$, however, SKF-38393 produced significant contraversive rotation $(71.4 \pm$ 13.9 turns $/ 10 \mathrm{~min} ; n=5$ ), and induced pronounced and widespread expression of Fos-like protein in the denervated caudoputamen (Fig. 6C). There was a complete absence of striosomal selectivity of the response in the distribution of the Fos-positive cells (cf. Fig. $6 C, D$ ) and no selectivity for the dorsolateral quadrant of the caudoputamen. Fos-positive neurons were not found in the globus pallidus of these animals. These results are in accord with those of $\mathrm{H}$. A. Robertson et al. (1989).

Effects of D1-selective and D2-selective antagonists. To investigate the relative contributions of pharmacologically defined D1-like and D2-like mechanisms to the synergistic responses, rats were given either the $\mathrm{D} 1$-selective antagonist $\mathrm{SCH}-23390$ $(0.5 \mathrm{mg} / \mathrm{kg}$ ) (group VI), the D2-selective antagonist raclopride $(2.0 \mathrm{mg} / \mathrm{kg}$ ) (group VII), or these drugs at the same doses in combination (group VIII) 30 min prior to sequential administration of SKF-38393 and quinpirole. Blockade of the synergistic behavioral response was achieved by prior administration of either SCH-23390 or raclopride, and the synergistic response was nearly eliminated by the combined administration of both antagonists (Table 1).

Pretreatment with SCH-23390 greatly attenuated, but did not eliminate, induction of Fos-like immunoreactivity in the denervated striatum of animals given combined D1/D2 treatment (Fig. 7A). Fos-positive cells were scattered through the caudoputamen, but there was no predominant dorsolateral immunostaining, and clusters of Fos-positive cells were rarely noted. SCH-23390 preadministration did not attenuate Fos-like protein expression in the globus pallidus (not shown). Raclopride pretreatment also caused a marked reduction in the D1/D2mediated Fos response (Fig. 7B). Preferential immunostaining of striosomes and the dorsolateral caudoputamen was eliminated. Some Fos-positive cells were scattered throughout the denervated striatum, but Fos-positive cells were more numerous in the striatum contralateral to the 6-OHDA lesion. Such activation of Fos-like protein and c-fos mRNA expression by D2 agonists has been previously reported (Dragunow et al., 1990; Graybiel et al., 1990; Miller, 1990). The induction of Fos-like protein was greatly reduced in both the globus pallidus and the cortex by pretreatment with raclopride (not shown). Pretreatment with the combination of SCH-23390 and raclopride almost completely suppressed expression of Fos-like protein in the denervated striatum (Fig. 7C), globus pallidus (Fig. $4 D$ ), and cortex (not shown).

Effects of $M K-801$ on D1/D2 synergistic responses. There is considerable evidence that glutamate-containing cortical afferents play a critical role in modulating the effects of dopamine within the striatum (Giorguieff et al., 1977; Clow and Jhamandas, 1989; Carlsson and Carlsson, 1990; Smith and Bolam, 1990). Accordingly, we examined the effects of MK-801, a noncompetitive antagonist of the NMDA receptor, on the D1/D2 synergistic responses in rats with unilateral lesions. MK-801 itself produced a marked dose-dependent effect on turning behavior (Fig. 1B). Immediately after injection, animals commenced turning in the direction opposite to that elicited by D1 or D2 agonists (i.e., ipsiversive rotation), a response that has been previously reported (Clineschmidt et al., 1982). The D1/D2 synergistic effect on contraversive rotation, which was produced by subsequent administration of SKF-38393 $(t=30 \mathrm{~min})$ and quinpirole $(t=70 \mathrm{~min})$, was completely blocked by the high dose $(1.0 \mathrm{mg} / \mathrm{kg})$ of MK-801 (mean \pm SEM of $3.5 \pm 3.0$ turns/
$10 \mathrm{~min})$ but was not affected by the lowest dose $(0.1 \mathrm{mg} / \mathrm{kg})$ (mean $\pm \mathrm{SEM}$ of $125.0 \pm 18.7 \mathrm{turns} / 10 \mathrm{~min}$ ). At $0.5 \mathrm{mg} / \mathrm{kg}$, MK-801 elicited a strong ipsiversive turning response that was partially, but transiently, reversed by subsequent SKF-38393 and quinpirole administration (mean \pm SEM of $6.49 \pm 15.11$ turns/10 $\mathrm{min}$ ).

The D1/D2-mediated induction of Fos-like protein in the caudoputamen was almost completely blocked by preadministration of either $0.5 \mathrm{mg} / \mathrm{kg}$ or $1.0 \mathrm{mg} / \mathrm{kg}$ MK-801 (Fig. $7 D$ ) but was unaffected by the lower dose $(0.1 \mathrm{mg} / \mathrm{kg}$; data not shown). A few cells with Fos-positive nuclei were present in the dorsomedial caudoputamen, but there was little immunoreactivity in the dorsolateral quadrant and a complete absence of striosome-selective immunostaining. Fos-like immunoreactivity in the globus pallidus and the neocortex was also greatly diminished by the two higher doses of MK-801.

\section{Discussion}

Synergistic interactions between D1-selective and D2-selective dopamine agonists

Synergistic interactions between agonists selective for D1-like and D2-like dopamine receptors have been repeatedly demonstrated at the behavioral level (Gershanik et al., 1983; Jackson and Hashizume, 1986; Mashurano and Waddington, 1986), including in the unilateral 6-OHDA-treated rat model of Parkinson's disease (Robertson and Robertson, 1986; Sonsalla et al., 1988). The findings we report here demonstrate that the combination of D1- and D2-selective agonists in this rat model produces a synergistic effect not only on behavior (rotation), but also on the levels of expression of the immediate-early gene c-fos and of Fos-like protein in the denervated caudoputamen. Moreover, our results demonstrate that the distribution of Fosimmunoreactive neurons in the striatum of rats treated with combined D1 and D2 agonists differs dramatically from the distribution of Fos-positive neurons in the striatum following administration of either agonist alone. In keeping with the view that expression of Fos may provide a measure of neuronal activity (Sagar et al., 1988; Morgan and Curran, 1991), we propose that these results provide evidence for a synergistic mechanism that involves the participation of distinct D1- and D2-responsive striatal output pathways.

Given at a low dose $(0.5 \mathrm{mg} / \mathrm{kg})$ to rats with unilateral 6-OHDA lesions, the D1-selective agonist SKF-38393 induced weak expression of Fos-like protein in the denervated caudoputamen and did not induce Fos-like immunoreactivity in the globus pallidus on either side. A low dose $(0.25 \mathrm{mg} / \mathrm{kg})$ of the D2-selective agonist quinpirole induced scant expression of Foslike protein in the caudoputamen, but did induce Fos-like protein in cells of the globus pallidus ipsilateral to the 6-OHDA lesion. Combined treatment with these low doses of SKF-38393 and quinpirole produced a marked synergistic increase not only on rotational behavior, but also on expression of Fos-like protein and hybridization signal for c-fos mRNA in the denervated striatum. Interestingly, the distribution of Fos-like immunoreactivity in the denervated striatum after synergistic activation of $\mathrm{D} 1$ and $\mathrm{D} 2$ receptors displayed a striking pattern that added two new features to the low-level striatal induction by the single agonists: intense induction in the dorsolateral quadrant of the caudoputamen and intense induction in striosomes. Fos-immunoreactive cells were present in the ipsilateral globus pallidus of these animals at levels comparable to those in rats treated with quinpirole alone. 

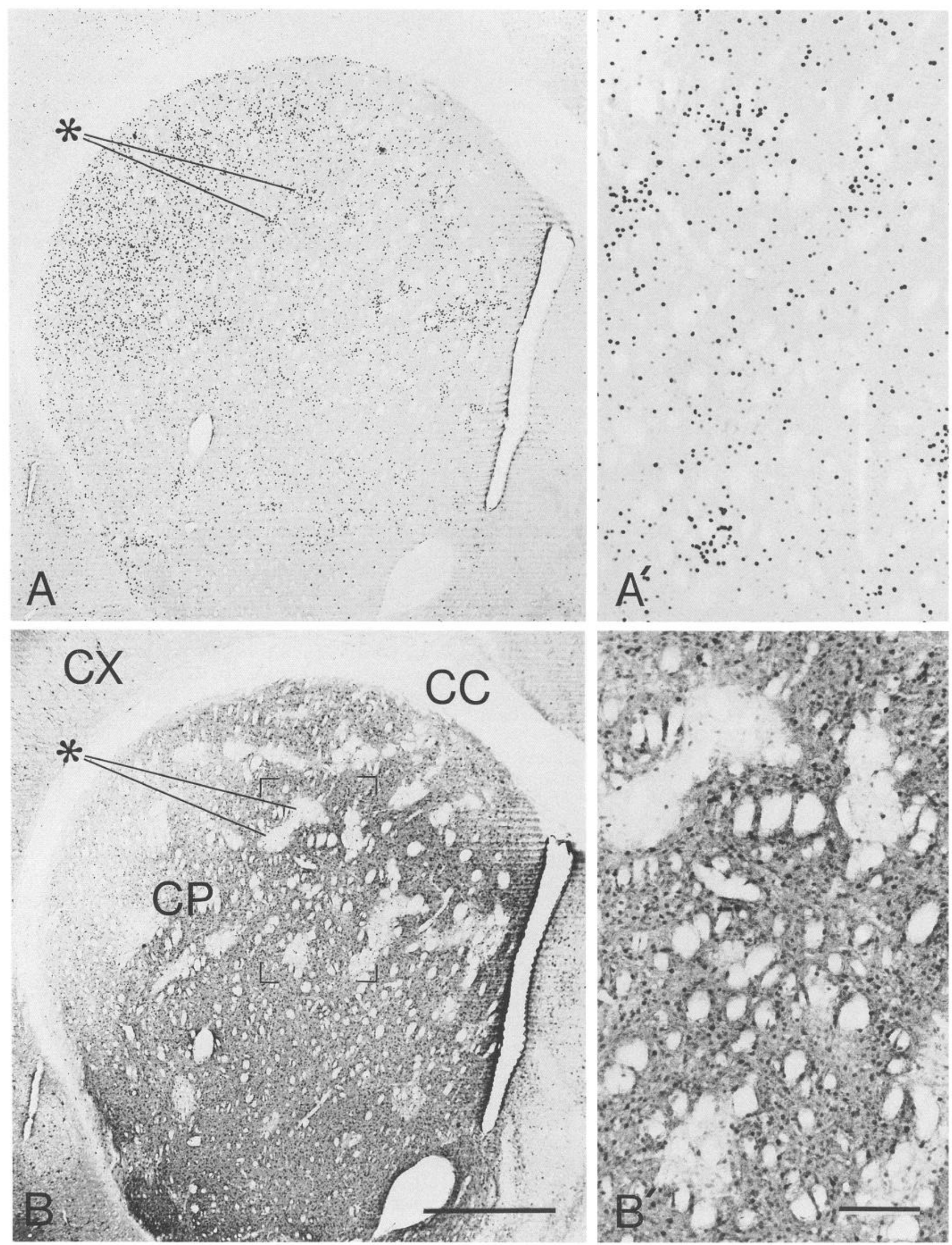

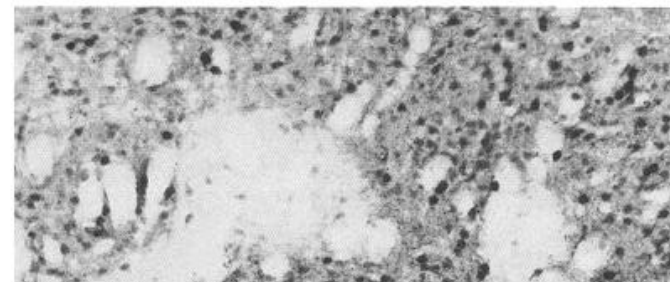
$\because \ldots+x^{2}$.

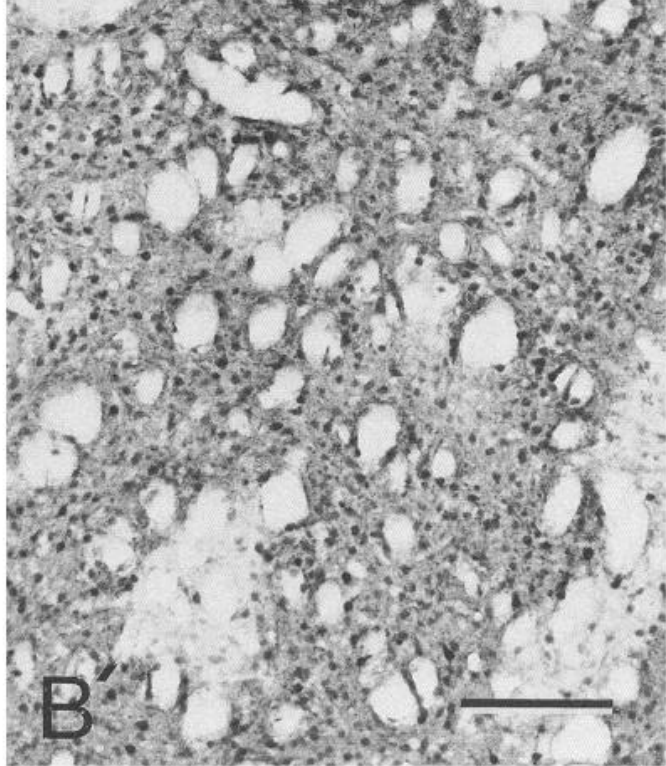




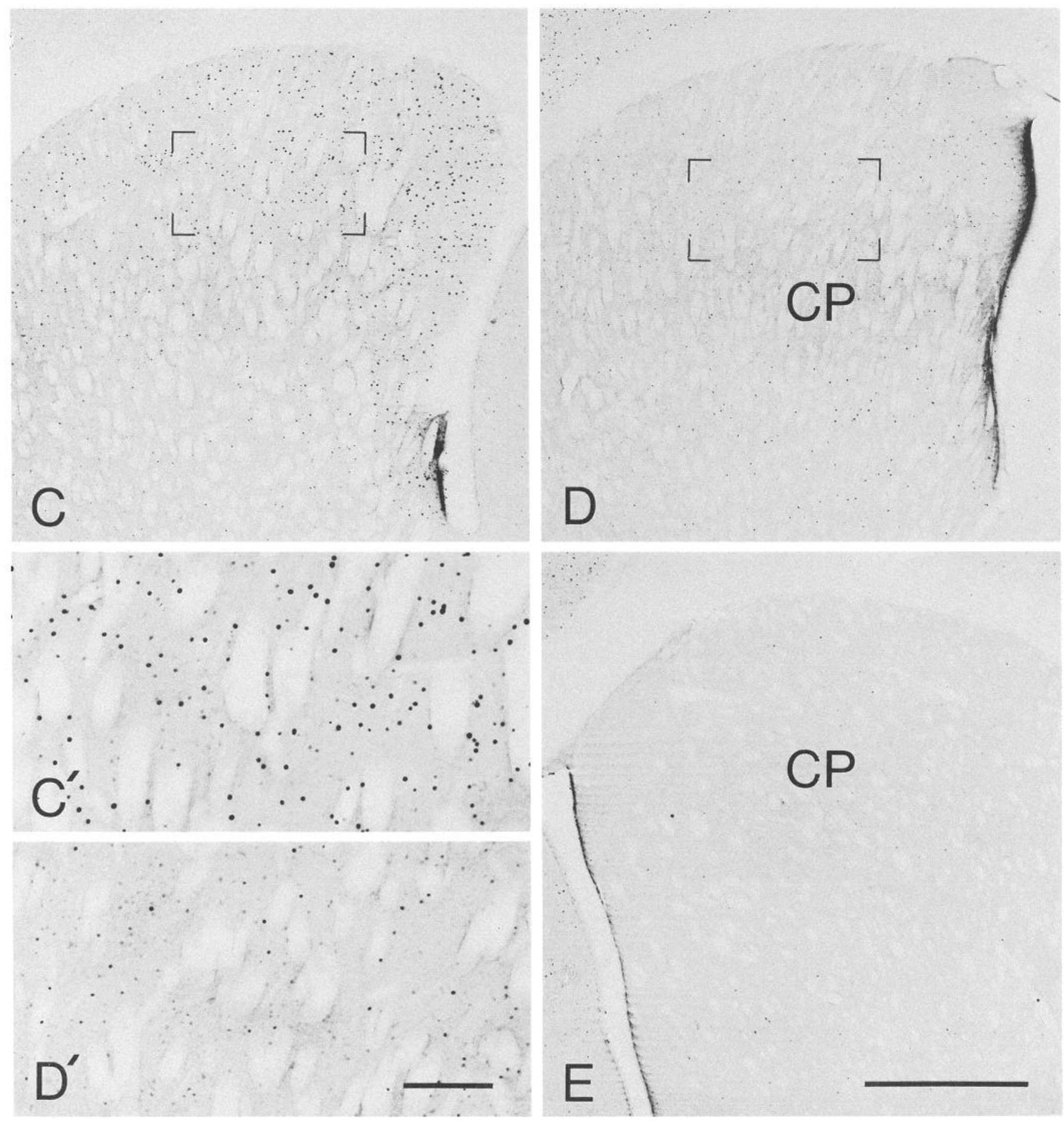

Figure 3. Photomicrographs illustrating distribution of Fos-positive nuclei in the striatum on the side of the 6-OHDA lesion in a rat treated with the sequential combination of $0.5 \mathrm{mg} / \mathrm{kg} \mathrm{SKF}-38393$ and $0.25 \mathrm{mg} / \mathrm{kg}$ quinpirole and perfused $2 \mathrm{hr}$ later. $A$, There is intense induction of Fos-like protein in the dorsolateral part of the caudoputamen and in cell clusters (examples at asterisk). $A^{\prime}$, Higher magnification view of the cell clusters (upper left shows the two marked by asterisk in $A$ ). $B$ and $B^{\prime}$, Photomicrographs of section adjacent to that illustrated in $A$ and $A^{\prime}$, stained for calbindin- $\mathrm{D}_{28 \mathrm{~K}}$. Note low expression of calbindin- $\mathrm{D}_{28 \mathrm{~K}}$ in striosomes (example at asterisk) and in the dorsolateral part of the caudoputamen. $C$, $C^{\prime}$ and $D, D^{\prime}$, Examples of low level of expression of Fos-like protein in the ipsilateral striatum of rats treated with $0.5 \mathrm{mg} / \mathrm{kg} \mathrm{SKF}-38393$ alone $(C)$ or $0.25 \mathrm{mg} / \mathrm{kg}$ quinpirole alone $(D) 2 \mathrm{hr}$ before perfusion. Fields indicated by brackets are shown at higher magnification in $B^{\prime}, C^{\prime}$ and $D^{\prime}$, respectively. $E$, Minimal expression of Fos-like protein in striatum contralateral to the 6-OHDA lesion in rat treated with combined SKF-38393 (0.5 mg/kg) and quinpirole $(0.25 \mathrm{mg} / \mathrm{kg}) . C P$, Caudoputamen; $C C$, corpus callosum. Scale bars: $A-E, 1 \mathrm{~mm} ; A^{\prime}-D^{\prime}, 200 \mu \mathrm{m}$. 

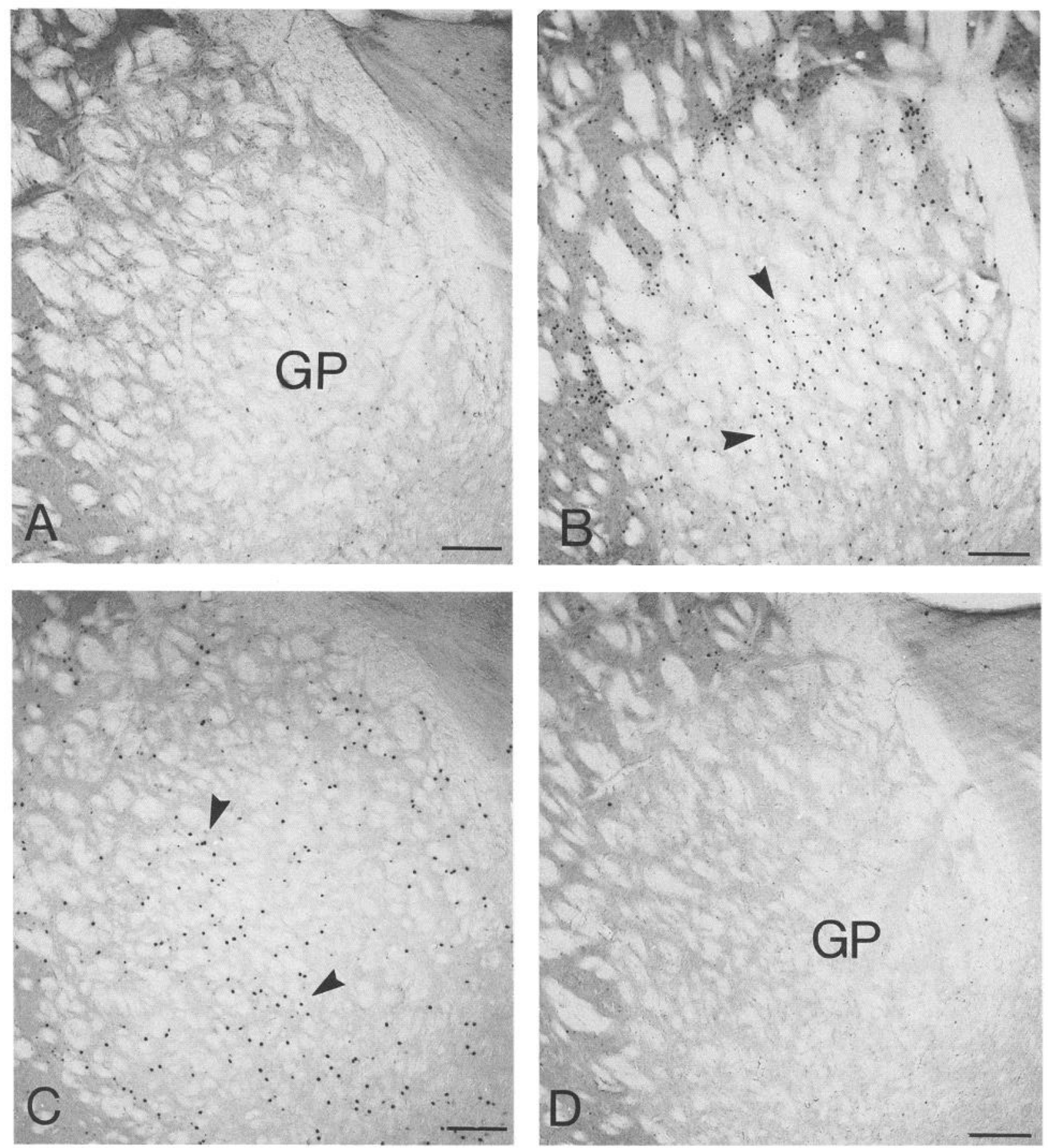

Figure 4. Photomicrographs of Fos-like immunoreactivity in transverse sections through the ipsilateral globus pallidus (GP) in animals with unilateral 6-OHDA lesions. SKF-38393 $(0.5 \mathrm{mg} / \mathrm{kg})$ alone (group I) induced little if any Fos-like protein $(A)$, but marked Fos-like immunostaining (arrowheads) was observed $(B)$ following single administration of quinpirole $(0.25 \mathrm{mg} / \mathrm{kg}$ ) (group II) and $(C)$ after combined administration of SKF38393 and quinpirole (group III). Preadministration of the combination of SCH-23390 (0.5 mg/kg) and raclopride (2.0 mg/kg) (group VIII) blocked the induction of Fos-like protein by combined D1/D2 treatment $(D)$. Scale bar, $0.8 \mathrm{~mm}$.

Several observations suggest that this synergistic induction of Fos-like protein in the striatum depended on interactions between D1 and D2 receptor-mediated mechanisms. First, there was relatively little Fos-like immunostaining in the denervated caudoputamen of animals that received two successive injections of either SKF-38393 $(0.5 \mathrm{mg} / \mathrm{kg})$ or quinpirole $(0.25 \mathrm{mg} /$ $\mathrm{kg}$ ) alone. In the latter case, the rats exhibited significant contraversive turning responses. The absence of a striatal Fos response following administration of D2 agonists has been pre- viously reported (H. A. Robertson et al., 1989), whereas in the present experiments the successive quinpirole injections did induce appreciable, although still sparse, Fos-like protein in striatal cells, including, rarely, cells in clusters. Nevertheless, the low level of response emphasizes the fact that the presence of Fos-like immunoreactivity in the striatal neurons is not simply a consequence of the turning behavior, for these animals turned vigorously. Second, although preadministration of either the D1 antagonist SCH-23390 or the D2 antagonist raclopride signifi- 
cantly reduced both the D1/D2-mediated behavioral response and induction of Fos-like protein, combined administration of both antagonists was necessary in order to suppress both behavior and induction of Fos-like protein completely. Third, administration of a single high dose $(2.0 \mathrm{mg} / \mathrm{kg})$ of SKF-38393 to rats with unilateral 6-OHDA lesions also produced both rotational behavior and activation of Fos-like immunoreactivity within the denervated striatum, as reported previously (H. A. Robertson et al., 1989), but the cells expressing Fos-like protein were widely distributed through the caudoputamen with no evidence of selectivity for the dorsolateral part of the caudoputamen or striosomes. Furthermore, a single administration of $1.0 \mathrm{mg} / \mathrm{kg}$ SKF-38393 evoked low rates of rotation and little striatal expression of Fos-like protein. Thus, neither high doses of D1 agonist nor two successive doses of either the D1 or the D2 agonist elicited the pattern of Fos-like immunoreactivity that was induced by combined D1 and D2 agonist treatment.

The synergistic Fos response observed in the dopamine-depleted caudoputamen involved two apparently quite different systems. The dorsolateral part of the caudoputamen, where the largest number of Fos-positive cells appeared, includes the territory receiving inputs from sensorimotor cortex and related cortical sites and has been singled out as receiving particularly sparse inputs from the amygdala and ventral tegmental area (Kelley et al., 1982). By contrast, the striosomes represent a dispersed system of neurochemically specialized neurons collected in branched labyrinths running through the caudoputamen that receive inputs from, inter alia, the rat's medial prefrontal cortex (Donoghue and Herkenham, 1986). As part of the sensorimotor striatum, the dorsolateral caudoputamen has extensive connections with targets in the pallidum and substantia nigra. The striosomal system is thought to project, at least in part, to the substantia nigra pars compacta and thus to exert control over dopamine-containing neurons there (Gerfen et al., 1985; Jiménez-Castellanos and Graybiel, 1989). Fos-positive cells were not exclusively collected in striosomes and the dorsolateral caudoputamen, but the concentration of Fos-positive cells elsewhere did not seem particularly more numerous than the Fos-positive cells in the strongest Fos-response seen in the single D1-agonist treated rats.

There is a clear precedent for the striosome-selective pattern of transcription factor induction. In normal rats treated with the indirect monoamine agonist amphetamine, there is preferential induction of nuclear Fos-like protein (Graybiel, 1990; Fuxe et al., 1991), and of NGFI- $A$ mRNA (Moratalla et al., 1992) in striosomes of the rostral caudoputamen. This pattern is different from the distribution of Fos-positive cells reported here, however. The compartmental selectivity fades caudally in the amphetamine-treated rats, and there is no hint of preferential induction of Fos-like protein in neurons of the dorsolateral quadrant. Grimes et al. (1990) have also reported briefly that chronic apomorphine treatment induces Fos-like immunoreactivity in patchy distributions in the caudoputamen.

With the marked contrasts in their anatomical connections, it is unlikely that the induction of Fos-like protein in the dorsolateral part of the caudoputamen and in the striosomes results from activation of a common set of afferent pathways. One feature that is shared by these two systems is the relatively low levels of calbindin- $\mathrm{D}_{28 \mathrm{~K}}$ staining. Striatal medium-sized neurons in both the dorsolateral part of the caudoputamen and in striosomes express little of this calcium-binding protein (Gerfen et al., 1985; Liu and Graybiel, in press). Conceivably, this could

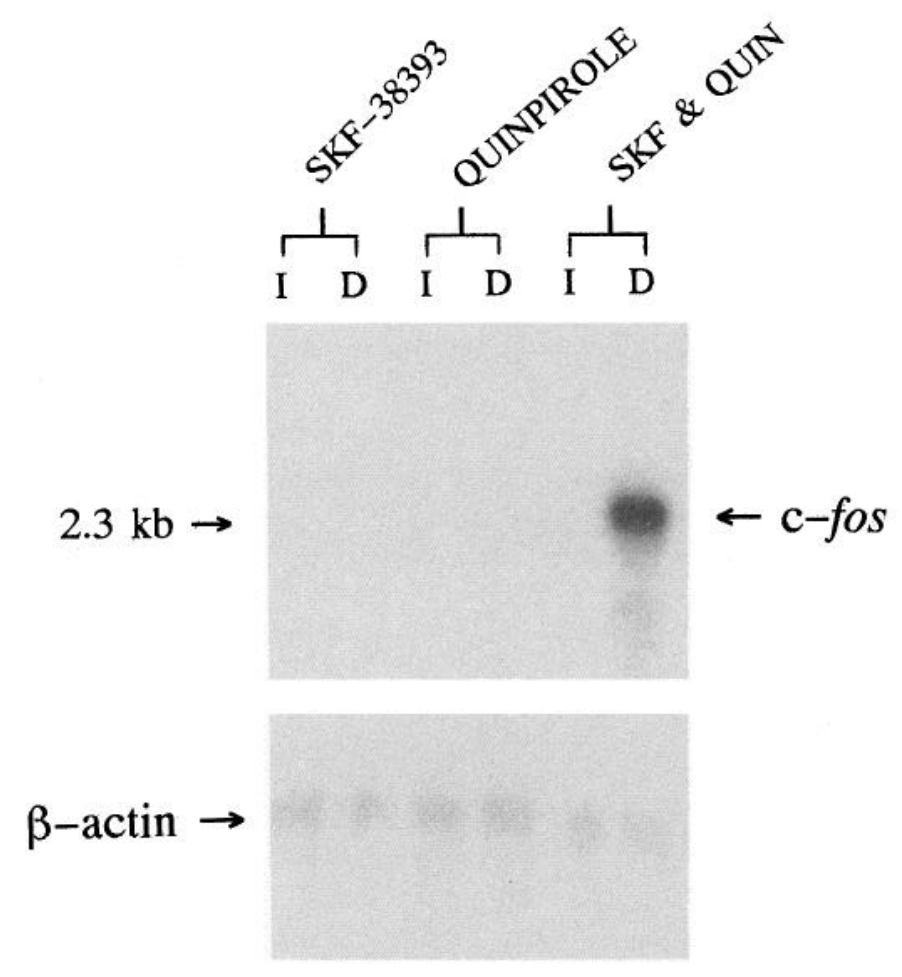

Figure 5. Representative Northern blot analysis of polyA ${ }^{+}$mRNA (1 $\mu \mathrm{g} /$ lane) from intact $(I)$ and denervated $(D)$ striata. Tissue was collected $45 \mathrm{~min}$ after administration of either SKF- $38393(0.5 \mathrm{mg} / \mathrm{kg})$, quinpirole $(0.25 \mathrm{mg} / \mathrm{kg})$, or the combination of both drugs to rats with unilateral 6-OHDA lesions ( $n=4$ per treatment group). $\beta$-Actin control blot is shown below.

influence the signaling paths leading to induction of the Foslike protein (Sheng and Greenberg, 1990; Berretta et al., in press).

\section{Activation of striatonigral and striatopallidal pathways}

Considerable evidence suggests that inhibition of the activity of GABA-containing neurons of the substantia nigra pars reticulata (and the consequent disinhibition of target motor nuclei) may mediate the contralateral turning behavior that is seen in rats with unilateral 6-OHDA lesions (Scheel-Kruger, 1986). Both contralateral rotation and inhibition of the activity of these neurons are produced by intranigral injection of GABA or the GABA agonist muscimol (Olianas et al., 1978; Waddington and Cross, 1978). The activity of these GABAergic nigral pars reticulata neurons is differentially modulated by two major striatal output pathways, the striatonigral system and the striatopallidal system projecting to the rat's globus pallidus. Both pathways arise from striatal medium-sized GABAergic neurons, but they are distinguished on the basis of different neuropeptide content, with striatal neurons projecting to the rat's globus pallidus containing enkephalin and striatonigral neurons containing substance P and dynorphin (Graybiel, 1990; Parent, 1990). These two pathways have opposite effects on the activity of GABAergic neurons in the substantia nigra pars reticulata. Activation of striatonigral neurons results in an increase in the output of GABA (Gauchy et al., 1980) and inhibition of the tonic activity of GABAergic pars reticulata neurons (Collingridge and Davies, 1981; Chevalier et al., 1985; Scheel-Kruger, 1986). Excitation of striatal outputs to the globus pallidus, which have an inhibitory influence on GABAergic neurons in the globus pallidus, results in disinhibition of the excitatory input from subthalamic 

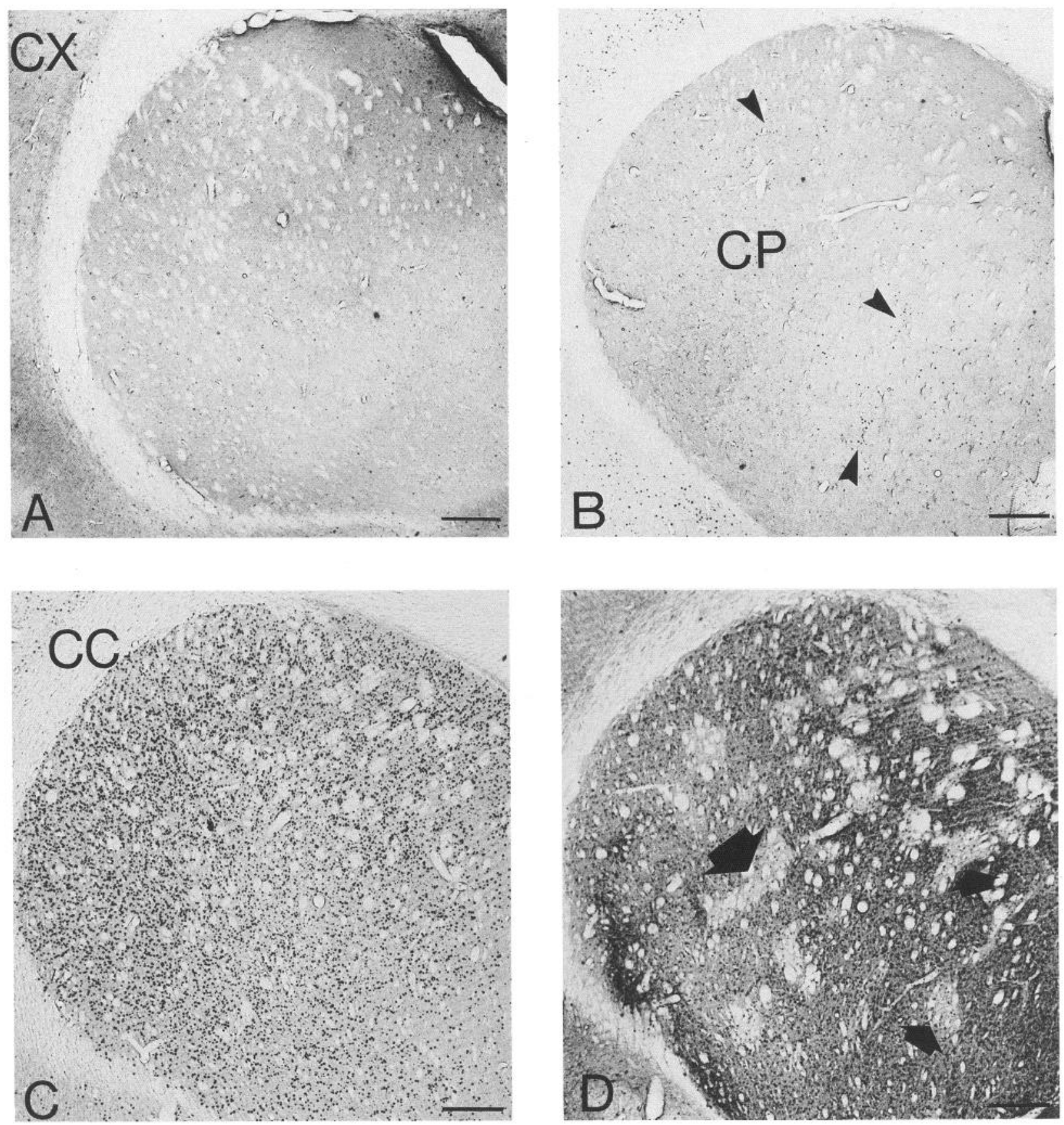

Figure 6. Photomicrographs of Fos-like immunoreactivity in transverse sections of the ipsilateral caudoputamen of rats with unilateral 6-OHDA lesions. Rats that received two successive injections $(t=30$ and $70 \mathrm{~min})$ of SKF-38393 $(0.5 \mathrm{mg} / \mathrm{kg})(\mathrm{group}$ IV) $(A)$, or quinpirole $(0.25 \mathrm{mg} / \mathrm{kg})$ (group V) (B), exhibited little Fos-like immunostaining (arrowheads). Animals that were given a single injection of a high dose (2.0 mg/kg) of SKF38393 showed robust and widespread expression of Fos-like protein $(C)$, but comparison with calbindin- $\mathrm{D}_{28 \mathrm{~K}}$-poor striosomes $($ arrows) in the adjacent section $(D)$ demonstrated a lack of striosomal selectivity. Scale bars, $1.1 \mathrm{~mm}$. $C C$, Corpus callosum; $C P$, caudoputamen; $C X$, cortex.

nucleus to the substantia nigra and increased tonic activity of neurons in the substantia nigra pars reticulata (Kita et al., 1983; Robledo and Féger, 1990). The activities of both the striatonigral and striatopallidal pathways are, in turn, predominantly modulated by afferents arising from the cortex and thalamus and by dopaminergic neurons that originate in the substantia nigra pars compacta (Albin et al., 1989; Graybiel, 1990; Parent, 1990).

There is evidence to suggest that D1-like and D2-like receptor subtypes may be differently associated with the two striatal efferent pathways. A preponderance of striatonigral neurons are thought to express D1-like receptors in high density (Gerfen et al., 1990; Harrison et al., 1990; Le Moine et al., 1990), whereas D2-like receptors are known to be expressed by enkephalinergic neurons, which project to the globus pallidus (Le Moine et al., 1990). Recent electrophysiological studies have shown that the D1-selective agonist SKF-38393 exerts excitatory effects on 6-OHDA denervated striatal neurons (Twery et al., 1991). If a 

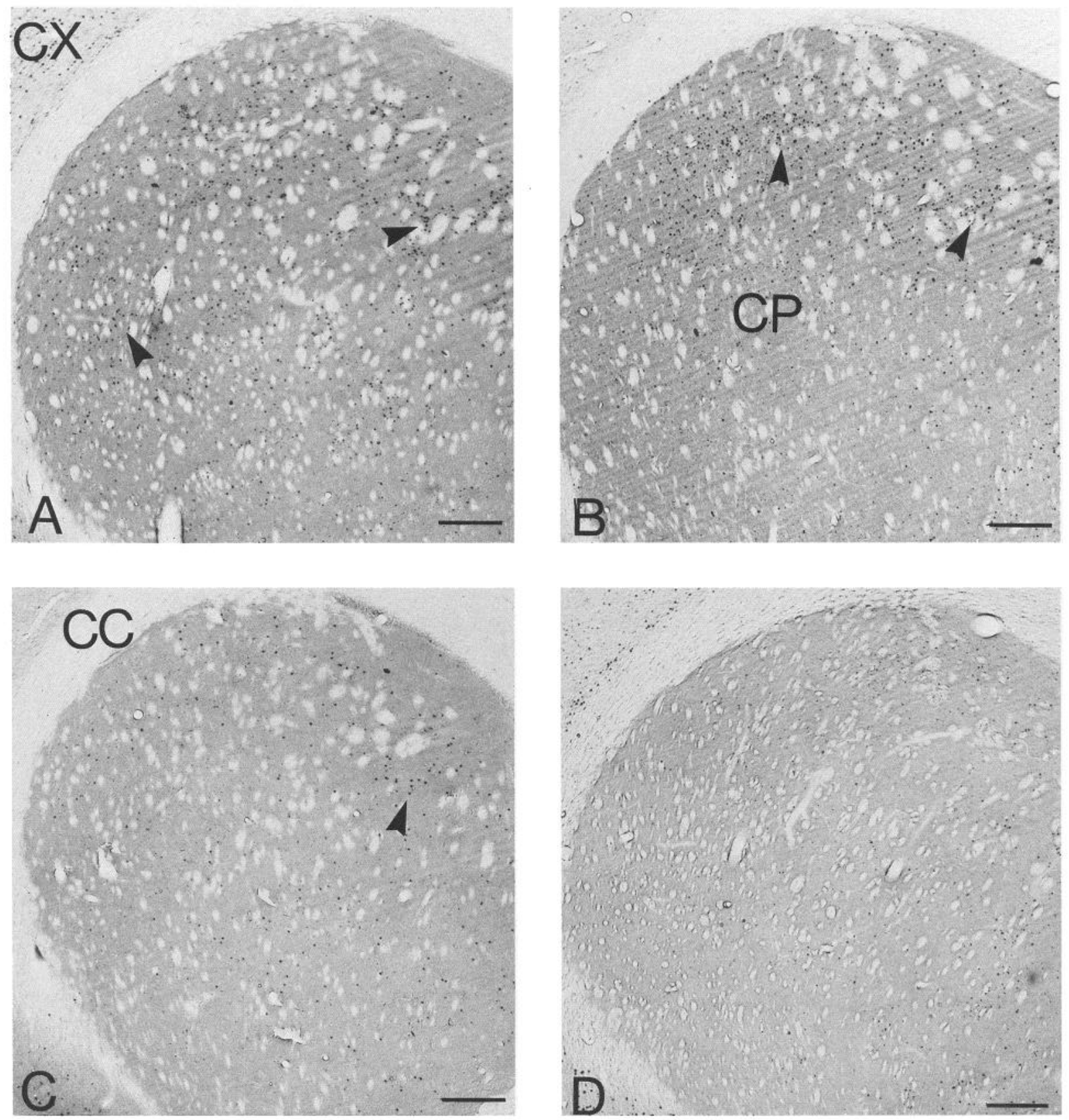

Figure 7. Induction of Fos-like immunoreactivity in the ipsilateral caudoputamen of rats with unilateral 6-OHDA lesions treated with combined administration of SKF-38393 $(0.5 \mathrm{mg} / \mathrm{kg})$ and quinpirole $(0.25 \mathrm{mg} / \mathrm{kg})$ (group III) but pretreated with dopamine receptor antagonists. The typically intense Fos response to the SKF-38393 plus quinpirole treatment (see Fig. 3) was greatly attenuated by preadministration of either the D1 antagonist $\mathrm{SCH}-23390(A, 0.5 \mathrm{mg} / \mathrm{kg})$ (group VI) or the D2 antagonist raclopride $(B, 2.0 \mathrm{mg} / \mathrm{kg})$ (group VII) and was nearly eliminated by pretreatment with the combination of both antagonists ( $C$, group VIII) or the NMDA receptor antagonist MK-801 (D, $0.5 \mathrm{mg} / \mathrm{kg})$. Arrowheads indicate Fos-positive neurons. $C C$, Corpus callosum; $C X$, cortex; $C P$, caudoputamen. Scale bars, $1.1 \mathrm{~mm}$.

Fos response were associated with such activation, D1 agonist stimulation might be expected to induce Fos-like protein in these neurons. This expected result was indeed noted in the present study in animals that were given SKF-38393 either alone or in combination with quinpirole. We have also shown that direct infusion of SKF-38393, but not quinpirole, can activate Fos-like protein expression in striatal neurons $(\mathrm{H}$. A. Robertson et al., 1990). Fos-like immunoreactivity induced in striatal neurons following treatment with amphetamine and cocaine has been shown to occur primarily in medium-sized neurons that express DARPP-32 (Berretta et al., in press), a dopamine- and cAMP-regulated phosphoprotein whose expression is thought to occur principally in neurons bearing D1-like dopamine receptors (Hemmings et al., 1984). The response to these agonists is blocked by the D1-selective antagonist SCH-23390 (Graybiel et al., 1990; Young et al., 1991). Moreover, others have reported that SKF-39393-mediated Fos induction in the denervated striatum of rats with unilateral 6-OHDA lesions is strongest in striatonigral neurons (G. S. Robertson et al., 1990a,b). If we take the Fos response as an indicator of physiological activation, 
then it is possible that D1-like receptors on striatonigral neurons help to mediate the inhibition of nigral pars reticulata neuronal activity and the accompanying contralateral turning response that are produced by systemic administration of SKF-38393 (Weick and Walters, 1987a). It is also important to take into account the role played by $\mathrm{DI}$ dopamine receptors in the substantia nigra in the behavioral synergistic response to Dl and D2 dopamine agonists (Robertson and Robertson, 1987, 1989; LaHoste and Marshall, 1990; Robertson, in press).

Dopamine agonist activation of neurons of the rat's striatopallidal output pathway inhibits the firing of cells in the globus pallidus (Bergstrom and Walters, 1981; Walters et al., 1987). Furthermore, the effects of dopamine on cell firing in the globus pallidus appear to be mediated by D2-like receptors but are potentiated or "enabled" by D1 activation (Walters et al., 1987). This inhibition of GABAergic striatopallidal input to the globus pallidus could, in addition to increasing pallidal cell firing, result in activation of Fos-like protein in these cells. In agreement with this prediction, in the present experiments we found Fos-like immunoreactivity in neurons of the globus pallidus only in animals that received the $\mathrm{D} 2$ agonist quinpirole, given either alone or in combination with SKF-38393. There was a striking absence of Fos-like immunoreactivity in the globus pallidus of animals that wcre given only the D1 agonist. Thus, according to the scheme proposed by Albin et al. (1989), it is conceivable that the D1/D2 synergistic behavior reported in the present study could have resulted from the Dl-mediated excitation of striatonigral neurons that inhibit the firing of nigral pars reticulata neurons, combined with the D2-mediated inhibition of the striatopallidal-subthalamic nucleus-pars reticulata pathway, which would have a similar inhibitory effect on the firing rate of neurons in the pars reticulata. Electrophysiological evidence in support of this view comes from earlier studies demonstrating that, in addition to the production of synergistic behavioral responses, SKF-38393-mediated inhibition of substantia nigra neuronal activity was potentiated by administration of a D2 agonist (Weick and Walters, 1987a,b).

It is interesting to note that a substantial number of neurons in the substantia nigra pars reticulata receive convergent inputs from the striatum and the globus pallidus (Smith and Bolam, 1991). Thus, the convergent mechanism proposed here has an anatomical counterpart. It is also important to point out, however, that the situation is more complex than a one-site convergence. First, the degree of coexpression of D1-like and D2like dopamine pathways on the striatal cells of origin of these pathways to the globus pallidus and the substantia nigra is still controversial. Some authors estimate coexpression of D1-like and D2-like dopamine receptor $\mathrm{mRNA}$ in striatal medium-sized cells to be as high as 30-50\% (Meador-Woodruff et al., 1991), and in a study of dopamine receptor mRNAs in single mediumsized striatal cells, the medium-sized neurons so far analyzed have expressed both D1-like and D2-like dopamine receptor mRNAs (D. J. Surmeier, C. J. Wilson, A. Stefani, and S. T. Kitai, personal communication). Most cells also show D1-like and D2-like modulation of sodium currents (Surmeier et al., 1991). Sccond, the connections of the system are more complex than the dual pathway model suggests (e.g., Graybiel, 1990, 1991; Hikosaka, 1991). Third, we found in our experiments that the glutamate NMDA receptor antagonist MK-801 blocked the synergistic induction of Fos-like protein and reversed the rotational behavior, suggesting an important role for glutamatergic inputs. Conceivably, glutamatergic influences, such as those de- rived from the massive corticostriatal innervation, could contribute to the patterns of Fos-like protein expression we found. Differences between the representation of D1-like and D2-like receptors in striosomes and matrix (Joyce et al., 1986; Besson et al., 1988; Loopuijt, 1989) and differences in their expression in the dorsolateral and medioventral caudoputamen (Loopuijt, 1989) could also be important. The degree of coexpression of these receptors could also vary across these striatal compartments and zones.

An alternative hypothesis for the mechanism underlying D1/ D2 synergistic responses is based upon the notion that D1-like and D2-like receptors are both present on a subset of striatal neurons (Seeman et al., 1989) and interact synergistically (Bertorello et al., 1990; Piomelli et al., 1991). As noted above, considerable coexpression of D1-like and D2-like mRNAs in striatal neurons has been suggested. Considerable colocalization of D1-associated DARPP-32 and D2-associated enkephalin has also been found by immunocytochemistry (Berretta et al., in press). The synergistic effects so far monitored (inhibition of $\mathrm{Na}^{+}$and $\mathrm{K}^{+}$ATPase activity and stimulation of arachidonic acid release) have so far been studied in vitro; it clearly would be of great interest to see whether they occur in vivo. Given these findings, however, perhaps the most reasonable hypothesis to put forward to account for our results is that both such cellular synergistic mechanisms and systems-level differentiation of receptor representations contribute to the striking D1/D2 synergistic effects we report.

Our findings may have important implications with respect to long-term changes in the brain in Parkinson's disease. We found striking differences in transcriptional response in the dopamine-depleted striatum after acute exposure to D1 and D2 agonists given singly and in combination. Although the molecular events that are triggered by the activation of immediateearly genes such as c-fos are unclear, it is conceivable that the subsequent expression of other late-response genes would contribute to significant and long-term changes in neuronal activity within the basal ganglia. Patients with Parkinson's disease are treated with such drug combinations, and are treated chronically during a time when continued loss of dopaminergic nigrostriatal fibers is likely to occur. It is reasonable to speculate that the functional consequences of prolonged treatment might include changing patterns of transcriptional activation, and that these might underlie some of the untoward effects of chronic dopaminergic therapy such as dystonia and dyskinesia (Klawans et al., 1990; Robertson et al., 1991).

\section{References}

Albin RL, Young AB, Penney JB (1989) The functional anatomy of basal ganglia disorders. Trends Neurosci 12:366-375.

Bergstrom DA, Walters JR (1981) Neuronal responses of the globus pallidus to systemic administration of $d$-amphetamine: investigation of the involvement of dopamine, norepinephrine, and serotonin. $J$ Neurosci 1:292-299.

Berretta S, Robertson HA, Graybiel AM (in press) Dopamine and glutamate agonists stimulate neuron-specific transcriptional activation of $\mathrm{c}-f \circ s$ in the striatum. J Neurophysiol, in press.

Bertorello AM, Hopfield JF, Aperia A, Greengard P (1990) Inhibition by dopamine of $\left(\mathrm{Na}^{++} \mathrm{K}^{+}\right)$ATPase activity in neostriatal neurons through D1 and D2 dopamine receptor synergism. Nature 347:386388.

Besson M-J, Graybiel AM, Nastuk M (1988) $\left[{ }^{3} \mathrm{H}\right] \mathrm{SCH} 23390$ binding to $\mathrm{D} 1$ dopamine receptors in the basal ganglia of the cat and primate: delineation of striosomal compartments and pallidal and nigral subdivisions. Neuroscience 26:101-119.

Bolam JP (1984) Synapses of identified neurons in the neostriatum. 
In: Functions of the basal ganglia (Evered D, O'Connor M, eds), pp 30-47. London: Pitman.

Calne DB, Teychenne P, Claveria LE, Eastman R, Greenacre JK, Petrie A (1974) Bromocriptine in Parkinsonism. Br Med J 4:442-444.

Carlsson M, Carlsson A (1990) Interactions between glutamatergic and monoaminergic systems within the basal ganglia-implications for schizophrenia and Parkinson's disease. Trends Neurosci 13:272276.

Chevalier G, Vacher S, Deniau JM, Desban M (1985) Disinhibition as a basic process in the expression of striatal function. I. The striatonigral influence on tecto-spinal/tecto-diencephalic neurons. Brain Res $334: 215-226$.

Chirgwin JM, Przybyla AE, Macdonald RJ, Rutter WJ (1979) Isolation of biologically active nucleic acid from sources enriched in ribonuclease. Biochemistry 18:5294-5299.

Clineschmidt BV, Martin GE, Bunting PR, Papp NL (1982) Central sympathomimetic activity of (+)-5-methyl-10,11-dihydro-5H-dibenzo [a,d] cyclohepten-5,10-imine (MK-801), a substance with potent anticonvulsant, central sympathomimetic, and apparent anxiolytic properties. Drug Dev Res 2:135-145.

Clow DW, Jhamandas K (1989) Characterization of L-glutamate action on the release of endogenous dopamine from the rat caudateputamen. J Pharmacol Exp Ther 248:722-728.

Collingridge GL, Davies J (1981) The influence of striatal stimulation and putative neurotransmitters on identified neurons in the rat substantia nigra. Brain Res 212:345-359.

Creese I, Fraser CM (1987) Receptor biochemistry and methodology, Vol 8, dopamine receptors, pp 1-245. New York: Liss.

Donoghue IP, Herkenham M (1986) Neostriatal projections from individual cortical fields conform to histochemically distinct striatal compartments in the rat. Brain Res 365:397-403.

Dragunow M, Robertson GS, Faull RLM, Robertson HA, Jansen K (1990) D2 dopamine receptor antagonists induce Fos and related proteins in rat striatal neurons. Neuroscience 37:287-294.

Fryberg EA, Kindle KL, Davidson N (1980) The actin genes of Drosophila: a dispersed multigene family. Cell 19:365-378.

Fuxe K, Agnati LF, Rosen L, Bjelke B, Cintra A, Bortolotti F, Tinner B, Andersson C, Hasselroth U, Steinbusch H, Gustatsson J-A, Benfenati $F$ (1991) Computer-assisted image analysis techniques allow a characterization of the compartments within the basal ganglia. Focus on functional compartments produced by $d$-amphetamine activation of the c-fos gene and its relation to the glucocorticoid receptor. J Chem Neuroanat 4:355-372.

Gauchy C, Kemel ML, Glowinski J, Besson MJ (1980) In vivo release of endogenously synthesized $\left[{ }^{3} \mathrm{H}\right]$ GABA from the cat substantia nigra and the pallido-entopeduncular nuclei. Brain Res 193:129-141.

Gerfen CR, Baimbridge KG, Miller JJ (1985) The neostriatal mosaic: compartmental distribution of calcium binding protein and parvalbumin in the basal ganglia of the rat and monkey. Proc Natl Acad Sci USA 82:8780-8784.

Gerfen CR, Engber TM, Mahan LC, Susel Z, Chase TN, Monsma FJ Jr, Sibley DR (1990) D1 and D2 dopamine receptor-regulated gene expression of striatonigral and striatopallidal neurons. Science 250: 1429-1432.

Gershanik O, Heikkila RE, Duvoisin RC (1983) Behavioral correlation of dopamine receptor activation. Neurology 33:1489-1492.

Giorguieff MF, Kemel ML, Glowinski J (1977) Presynaptic effect of L-glutamic acid on the release of dopamine in rat striatal slices. Neurosci Lett 6:73-77.

Graybiel AM (1990) Neurotransmitters and neuromodulators in the basal ganglia. Trends Neurosci 13:244-254.

Graybiel AM (1991) Basal ganglia-input, neural activity, and relation to the cortex. Curr Opin Neurobiol 1:644-651.

Graybiel AM, Moratalla R, Robertson HA (1990) Amphetamine and cocaine induce drug-specific activation of the c-fos gene in striosomematrix and limbic subdivisions of the striatum. Proc Natl Acad Sci USA 87:6912-6916.

Grimes LM, Ping X, Jiang H-K, Hong J-S (1990) Striatal patch/matrix distribution of Fos, substance $P$ and dynorphin induced by apomorphine in intact and 6-OHDA lesioned rats. Soc Neurosci Abstr 16: 800.

Harrison MB, Wiley RG, Wooten GF (1990) Selective localization of striatal D1 receptors to striatonigral neurons. Brain Res 528:317-322.

Hemmings IIC, Greengard P, Lim Tung HY, Cohen P (1984) DARPP32 , a dopamine regulated neuronal phosphoprotein, is a potent inhibitor of protein phosphatase-1. Nature 310:503-505.
Herrera-Marschitz M, Ungerstedt U (1984a) Evidence that striatal efferents relate to different dopamine receptors. Brain Res 323:269278.

Herrera-Marschitz M, Ungerstedt U (1984b) Evidence that apomorphine and pergolide induce contralateral rotation in rats by different actions on D1 and D2 receptor sites. Eur J Pharmacol 98:165-176.

Hikosaka O (1991) Basal ganglia-possible role in motor coordination and learning. Curr Opin Neurobiol 1:638-643.

Hornykiewicz O (1979) Dopamine in Parkinson's disease and other neurological disturbances. In: The neurobiology of dopamine (Horn AS, Korf J, Westerink BHC, eds), pp 633-654. London: Academic.

Hsu SM, Raine L, Fanger H (1981) Use of avidin-biotin-peroxidase (ABC) in immunoperoxidase techniques. J Histochem Cytochem 29: $577-585$.

Jackson DM, Hashizume M (1986) Bromocriptine induces marked locomotor stimulation in dopamine-depleted mice when D-1 dopamine receptors are stimulated with SK \& F 38393. Pyschopharmacology 90:147-153.

Jiang H-K, McGinty JF, Hong JS (1990) Differential modulation of striatonigral dynorphin and enkephalin by dopamine receptor subtypes. Brain Res 507:57-64.

Jiménez-Castellanos J, Graybiel AM (1989) Compartmental origins of striatal efferent projections in the cat. Neuroscience 32:297-321.

Joyce JN, Sapp DW, Marshall JF (1986) Human striatal dopamine receptors are organized in compartments. Proc Natl Acad Sci USA 83:8002-8006.

Kebabian JW, Calne DB (1979) Multiple receptors for dopamine. Nature 277:93-96.

Kelley AF, Domesick VR, Nauta WJH (1982) The amygdalostriatal projection in the rat-an anatomical study by anterograde and retrograde tracing methods. Neuroscience 7:615-630.

Kita H, Chang HT, Kitai ST (1983) Pallidal inputs to subthalamus: intracellular analysis. Brain Res 264:255-265.

Klawans HL, Hitri A, Barr A (1990) Levodopa-induced dyskinesias. In: Parkinson's disease (Stern G, ed), pp 537-557. Baltimore: Johns Hopkins UP.

Koob GF, Bloom FE (1988) Cellular and molecular mechanisms of drug dependence. Science 242:715-723.

LaHoste GJ, Marshall JF (1990) Nigral D1 and striatal D2 receptors mediate the behavioral effects of dopamine agonists. Behav Brain Res 38:233-242.

Le Moine C, Normand E, Guitteny AF, Fouque B, Teoule R, Bloch B (1990) Dopamine receptor gene expression by enkephalin neurons in rat forebrain. Proc Natl Acad Sci USA 87:230-234.

Liu F-C, Graybiel AM (in press) Heterogeneous development of calbindin- $\mathrm{D}_{28 \mathrm{~K}}$ expression in the developing striatum. J Comp Neurol, in press.

Loopuijt LD (1989) Distribution of dopamine D-2 receptors in the rat striatal complex and its comparison with acetylcholinesterase. Brain Res Bull 22:805-817.

Mahan LC, Burch RM, Monsma FJ Jr, Sibley DR (1990) Expression of striatal D1 dopamine receptors coupled to inositol phosphate production and $\mathrm{Ca}^{2+}$ mobilization in Xenopus oocytes. Proc Natl Acad Sci USA 87:2196-2200.

Mashurano M, Waddington JL (1986) Stereotyped behaviour in response to the selective D-2 dopamine receptor agonist RU 24213 is enhanced by pretreatment with the selective D-1 agonist SK\&F 38393. Neuropharmacology 25:947-949.

Meador-Woodruff JH, Mansour A, Healy DJ, Kuehn R, Zhou Q-Y, Bunzow JR, Akil H, Civelli O, Watson SJ Jr (1991) Comparison of the distributions of $D_{1}$ and $D_{2}$ dopamine receptor mRNA in rat brain. Neuropsychopharmacology 5:231-242.

Miller JC (1990) Induction of c-fos mRNA expression in rat striatum by neuroleptic drugs. J Neurochem 54:1453-1455.

Mocchetti I, Naranjo JR, Costa E (1985) Use of mRNA hybridization and radioimmunoassay to study mechanisms of drug-induced accumulation of enkephalin in rat brain structures. Mol Pharmacol 28: $86-91$.

Moratalla R, Robertson HA, Graybiel AM (1992) Dynamic regulation of $N G F I-A$ (zif $268, e g r 1)$ gene expression in the striatum. J Neurosci $12: 2609-2622$

Morgan JI, Curran T (1991) Stimulus-transcription coupling in the nervous system: involvement of the inducible proto-oncogenes fos and jun. Annu Rev Neurosci 14:421-451.

Olianas MC, De Montis GM, Mulas G, Tagliamonte A (1978) The striatal dopaminergic function is mediated by the inhibition of a 
nigral, non-dopaminergic neuronal system via a strio-nigral GABAergic pathway. Eur J Pharmacol 49:233-241.

Parent A (1990) Extrinsic connections of the basal ganglia. Trends Neurosci 13:254-258.

Paxinos G, Watson C (1985) The rat brain in stereotaxic coordinates. New York: Academic.

Piomelli D, Pilon C, Giros B, Sokoloff P, Martres M-P, Schwartz J-C (1991) Dopamine activation of the arachidonic acid cascade as a basis for D1/D2 receptor synergism. Nature 353:164-167.

Rinne U (1987) Early combination of bromocriptine and levodopa in the treatment of Parkinson's disease: a 5-year follow-up. Neurology $37: 826-828$.

Robertson GS, Robertson HA (1986) Synergistic effects of D1 and D2 dopamine agonists on turning behaviour in rats. Brain Res 384:384 387.

Robertson GS, Robertson HA (1987) D1 and D2 dopamine agonist synergism: separate sites of action. Trends Pharamacol Sci 8:295299.

Robertson GS, Robertson HA (1989) L-Dopa induced rotational behavior is dependent on both striatal and nigral mechanisms. J Neurosci 9:3326-3331.

Robertson GS, Herrera DG, Dragunow M, Robertson HA (1989) L-Dopa activates c-fos expression in the striatum of 6-hydroxydopamine-lesioned rats. Eur J Pharmacol 159:99-100.

Robertson GS, Vincent SR, Fibiger HC (1990a) Striatonigral projection neurons contain D1 dopamine receptor-activated $\mathrm{c}-$ fos. Brain Res 523:288-290.

Robertson GS, Vincent SR, Fibiger HC (1990b) D1 receptor activation induces $c$ - $f \circ s$ expression in striato-nigral neurons following denervation. Soc Neurosci Abstr 16:1.

Robertson HA (1992) Dopamine receptor interactions: some implications for the treatment of Parkinson's disease. Trends Neurosci 15: 201-206.

Robertson HA, Peterson MR, Murphy K, Robertson GS (1989) D1dopamine receptor agonists selectively activate striatal c-fos independent of rotational behavior. Brain Res 503:346-349.

Robertson HA, Graybiel AM, Paul ML (1990) Activation of rat striatal c-fos by direct infusion of dopaminergic agonists and forskolin. Soc Neurosci Abstr 16:1232.

Robertson HA, Paul ML, Moratalla R, Graybiel AM (1991) Expression of the immediate-early gene c-fos in basal ganglia: induction by dopaminergic drugs. Can J Neurol Sci [Suppl] 18:380-383.

Robledo P, Féger J (1990) Excitatory influence of rat subthalamic nucleus to substantia nigra pars reticulata and the pallidal complex: electrophysiological data. Brain Res 518:47-54.

Sagar SM, Sharp FR, Curran T (1988) Expression of c-fos protcin in brain: metabolic mapping at the cellular level. Science 240:13281331.

Scheel-Kruger J (1986) Dopamine-GABA interactions: evidence that GABA transmits, modulates and mediates dopaminergic functions in the basal ganglia and the limbic system. Acta Neurol Scand 73:154.

Seeman P, Niznik HB, Guan H-C, Booth G, Ulpian C (1989) Link between $\mathrm{D} 1$ and $\mathrm{D} 2$ dopamine receptors is reduced in schizophrenia and Huntington's disease. Proc Natl Acad Sci USA 86:10156-10160.

Sheng M, Greenberg ME (1990) The regulation and function of c-fos and other immediate early genes in the nervous system. Neuron 4 : $477-485$.

Smith AD, Bolam JP (1990) The neural network of the basal ganglia as revealed by the study of synaptic connections of identified neurons. Trends Neurosci 13:259-265.

Smith Y, Bolam JP (1991) Convergence of synaptic inputs from the unilateral lesions of the dopaminergic nigrostriatal pathway. J Pharmacol Exp Ther 247:180-185.

Sokoloff P, Giros B, Martres M-P, Bouthenet M-L, Schwartz J-C (1990) Molecular cloning and characterization of a novel dopamine receptor $\left(D_{3}\right)$ as a target for neuroleptics. Nature 347:146-151.

Sonsalla PK, Manzino L, Heikkila RE (1988) Interactions of D1 and D2 dopamine receptors on the ipsilateral vs. contralateral side in rats with unilateral lesions of the dopaminergic nigrostriatal pathway. $J$ Pharmacol Exp Ther 247:180-185.

Stoof JC, Kebabian JW (1981) Opposing roles for D-1 and D-2 dopamine receptors in efflux of cyclic AMP from rat neostriatum. Nature 294:366-368.

Sunahara RK, Guan H-C, O'Dowd BF, Seeman P, Laurier LG, Ng G, George SR, Torchia J, Van Tol HHM, Niznik HB (1991) Cloning of the gene for a human dopamine D5 receptor with higher affinity for dopamine than D1. Nature 350:614-619.

Surmeier DJ, Wilson CJ, Stefani A, Kitai ST (1991) Dopaminergic modulation of sodium currents in retrogradely-identified rat striatonigral neurons. Soc Neurosci Abstr 17:851.

Twery MJ, Thompson LA, Walters JR (1991) SKF 38393 increases the excitability of striatal neurons ipsilateral to 6-hydroxydopamineinduced dopamine cell lesions and decreases the excitability of neurons in contralateral striatum in vitro. Eur J Neurosci [Suppl] 4:146.

Van Tol HHM, Bunzow JR, Guan H-C, Sunahara RK, Seeman P, Niznik HB, Civelli O (1991) Cloning of the gene for a human dopamine D4 receptor with high affinity for the antipsychotic clozapine. Nature 350:610-614.

Waddington JL, Cross AJ (1978) Denervation supersensitivity in the striatonigral GABA pathway. Nature 276:618-620.

Walters JR, Bergstrom DA, Carlson JH, Chase TN, Braun AR (1987) D1 dopamine receptor activation required for postsynaptic expression of D2 agonist effects. Science 236:719-722.

Weick BG, Walters JR (1987a) Effects of D1 and D2 dopamine receptor stimulation on the activity of substantia nigra pars reticulata neurons in 6-hydroxydopamine lesioned rats: D1/D2 coactivation induces potentiated responses. Brain Res 405:234-246.

Weick BG, Walters JR (1987b) D1 dopamine receptor stimulation potentiates neurophysiological effects of bromocriptine in rats with lesions of the nigrostriatal pathway. Neuropharmacology 26:641-644.

Weick BG, Engber TM, Susel Z, Chase TN, Walters JR (1990) Responses of substantia nigra pars reticulata neurons to GABA and SKF 38393 in 6-hydroxydopamine-lesioned rats are differentially affected by continuous and intermittent levodopa administration. Brain Res 523:16-22.

Wong EHF, Kemp JA, Priestley T, Knight AR, Woodruff GN, Iversen LL (1986) The anticonvulsant MK-801 is a potent $N$-methyl-Daspartate antagonist. Proc Natl Acad Sci USA 83:7104-7108.

Young ST, Porrino LJ, Iadorola MJ (1991) Cocaine induces striatal c-fos-immunoreactive proteins via dopaminergic D1 receptors. Proc Natl Acad Sci USA 88:1291-1295. 